Jurnal PG-PAUD Trunojoyo : Jurnal Pendidikan dan Pembelajaran Anak Usia Dini, Volume 7, Nomor 2, Oktober 2020 hal 52-61, ISSN : 2528-3553 (online), ISSN: 2407-4454 (print)

\title{
POLA ASUH ORANG TUA BAGI ANAK YANG MENGALAMI GANGGUAN BERBICARA DI DESA KOTA TANAH KECAMATAN SEMENDAWAI TIMUR KABUPATEN OKU TIMUR
}

\author{
Yolanda Tifani ${ }^{1}$ \\ Bukman Lian ${ }^{2}$ \\ Santa Idaya Sinaga ${ }^{3}$ \\ 1,2,3PG-PAUD, Universitas PGRI Palembang \\ Email:yolandatifani97@gmail.com,drbukmanlian@univpgri-palembang.ac.id,paudsanta@gmail.com
}

Received (Juni), Accepted (September), Published (Oktober)

\begin{abstract}
Parenting Style for Children with Talking Disorders in the Village, Kota Tanah, Semendawai Timur District, East Oku Regency. The parenting style used by parents in educating children with speech disorders can also greatly affect and have an impact on the child's personality later. The purpose of this study was to determine the impact and ways of dealing with children with speech disorders. The research method used in this research is a case study, in this study the object of research is a child with speech disorders consisting of 1 (one) person. The data that will be analyzed are observation, interview and documentation. The results of this study indicate that parenting has a negative impact on children with speech disorders, namely problems with children's growth and development that will be different from children in general. The impact that children experience is the lack of socializing with friends or the surrounding environment because children who experience speech disorders are often ostracized by their friends, making the child more moody and quiet.
\end{abstract}

Keywords: parenting style, disorder, talking, children, parents.

Abstrak: Pola Asuh Orangtua Bagi Anak yang Mengalami Gangguan Berbicara di Desa Kota Tanah Kecamatan Semendawai Timur Kabupaten Oku Timur. Pola asuh yang digunakan orang tua dalam mendidik anak yang mengalami gangguan berbicara itu juga bisa sangat mempengaruhi dan berdampak pada kepribadian anak nantinya. Tujuan penelitian ini untuk mengetahui dampak dan cara mengatasi anak yang mengalami gangguan berbicara. Metode penelitian yang digunakan dalam penelitian ini adalah studi kasus, pada penelitian ini objek penelitiannya adalah anak yang mengalami gangguan berbicara yang terdiri dari 1 (satu) orang. Data yang akan dianalisis adalah observasi, wawancara dan dokumentasi. Hasil penelitian ini menunjukkan bahwa pola asuh berdampak negative bagi anak yang mengalami gangguan berbicara yaitu masalah pada pertumbuhan dan perkembangan anak yang akan berbeda dengan anak pada umumnya. Dampak yang anak alami adalah kurangnya bersosialisasi dengan teman atau lingkungan sekitarnya karena anak yang mengalami gangguan berbicara ini sering kali dikucilkan oleh teman-temannya sehingga membuat anak tersebut lebih murung dan pendiam.

Kata kunci: pola asuh, gangguan, berbicara, anak, orangtua 
Jurnal PG-PAUD Trunojoyo : Jurnal Pendidikan dan Pembelajaran Anak Usia Dini, Volume 7, Nomor 2, Oktober 2020 hal 52-61, ISSN : 2528-3553 (online), ISSN: 2407-4454 (print)

\section{PENDAHULUAN}

Pendidikan anak usia dini merupakan suatu upaya pembinaan yang ditujukan bagi anak sejak lahir sampai dengan usia enam tahun. Pendidikan anak usia dini memperhatikan pertumbuhan karakteristik anak dalam beradaptasi dan bersosialisasi di lingkungannya. Pada masa ini pertumbuhan dan perkembangan anak sangat pesat sekali sehingga rasa ingin tahu anak sangat tinggi.

Anak usia dini berada dalam rentang usia 0-6 tahun (golden age). Masa anak usia dini adalah masa emas yang bila mana pada masa itu anak dapat meniru semua kegiatan yang dilakukan oleh orang tuanya ataupun orang-orang yang adasekitarnya. Mendidik anak dengan menggunakan ilmu akan menjadikan orang tua lebih bijaksana sehingga dapat membantu dan mengembangkan anak secara tepat menjadi manusia seutuhnya.

Bahasa adalah alat komunikasi untuk bersosialisasi dan beradaptasi dengan orang lain, yang artinya tidak ada seorangpun yang berkomunikasi tanpa menggunakan bahasa. Bahasa anak dapat berkembang cepat apabila anak mempunyai kemampuan yang didukung oleh lingkungan sekitarnya. Seorang anak harus menambah pengetahuannya akan berbahasa melalui pengalaman kehidupannya sehari-hari di dalam lingkungan keluarga maupun di lingkungan sekitar rumahnya. Anak masih harus banyak belajar sehingga nantinya mempunyai lebih banyak kosakata.

Keterlambatan berbicara tertuju langsung pada hambatan perkembangan pada anak. Jika anak mengalami hambatan pada perkembangan maka itu juga akan menghambat perkembangan yang lainnya, masalah keterlambatan berbicara adalah masalah yang sangat serius karena jika anak tidak dapat berbicara otomatis anak tidak dapat bersosialisasi dengan teman-teman sebayanya. Keterlambatan berbicara harus segera ditangani karena salah satu yang menyebabkan gangguan perkembangan yang sering ditemukan pada anak oleh karena itu keterlambatan berbicara dapat diketahui melalui penggunaan kata dengan pengucapan yang tidak jelas dan terkadang berkomunikasi menggunakan bahasa isyarat, sehingga membuat orang-orang sekitarnya kurang dapat memahami apa yang dimaksud oleh anak.

Berdasarkan observasi yang telah dilakukan di lapangan subjek penelitian merupakan seorang anak perempuan, bernama Munawaroh yang biasanya di panggil mumun, yang sekarang umurnya lima tahun. Mumun sedari kecil memang tidak berbicara tetapi dia mengerti apa yang orang lain bicarakan saat mengajaknya ngobrol. Hal itulah mungkin yang membuat orang tua mumun menganggap bahwa mumun tidak mengalami hambatan apapun. Tetapi jika dilihat-lihat lagi sampai umur mumun lima tahun lebih beberapa bulan ini mumun belum sepenuhnya berbicara tetapi mumun bisa memanggil nama-nama orangorang tertentu saja seperti memanggil kedua orang tuanya seperti mengutarakan kata "mak" untuk memanggil ibu, "pak" untuk memanggil ayah, "mbah" untuk memanggil nenek dan kakeknya dan satu teman sebayanya mumun mengutarakan kata "' pisa" untuk memanggil nafisa.

Harapan peneliti dengan adanya penelitian ini dapat memberitahu kepada semua masyarakat khususnya orang tua agar lebih memperhatikan anak mereka.Jika anak mengalami hambatan atau gangguan pada perkembangannya agar segera di atasi atau diperiksa ke yang ahlinya.

Berdasarkan penelitian yang dilakukan oleh Wenty Anggraini dengan judul "Keterlambatan Bicara (Speech Delay) Pada Anak (Studi Kasus Anak 5 Tahun)". Hasil penelitian menunjukkan bahwa terdapat 12 faktor yang mempengaruhi kerterlambatan bicara pada anak tersebut adalah multilingual, model yang baik untuk ditiru, kurangnya kesempatan untuk berpraktek bicara, kurangnya motivasi untuk berbicara, 
Jurnal PG-PAUD Trunojoyo : Jurnal Pendidikan dan Pembelajaran Anak Usia Dini, Volume 7, Nomor 2, Oktober 2020 hal 52-61, ISSN : 2528-3553 (online), ISSN: 2407-4454 (print)

dorongan bimbingan, hubungan dengan teman sebaya, penyesuaian diri, kelahiran kembar, jenis kelamin, dan besarnya keluarga, kebiasaaan anak dalam menonton televisi, dan kurangnya pengetahuan akan hambatan tersebut.

Pola asuh adalah untuk mengembangkan kemampuan yang dimiliki sejalan dengan tahap perkembangannya dan untuk mendorong peningkatan kemampuan dalam berperilaku sesuai dengan nilai agama dan moral yang dianut.

Helmawati (2014) menyatakan macammacam pola asuh orang tua terhadap anak adalah sebagai berikut:

\section{A. Pola Asuh Otoriter}

Pola asuh otoriter pada umumnya menggunakan pola komunikasi satu arah. Ciri-ciri pada pola asuh ini menekankan bahwa segala aturan orang tua harus ditaati oleh anaknya. Inilah yang dinamakan win-lose solution. Orang tua memaksakan pendapat atau keinginan pada anaknya dan bertindak semena-mena (semaunya kepada anak), tanpa dapat dikritik oleh anak. Menurut Septiari (Wibowo, 2018) pola asuh otoriter ini akan berakibat buruk bagi kepribadian anak. Akibat yang ditimbulkan dari pola asuh ini yaitu, anak menjadi penakut, pencemas,, menarik diri dari pergaulan, kurang adaptif, kurang tajam, kurang tujuan, curiga terhadap orang lain dan mudah stress.

\section{B. Pola Asuh Permisif}

Pada umumnya pola asuh permisif ini menggunakan komunikasi satu arah karena meskipun orang tua memiliki kekuasaan penuh dalam keluarga terutama terhadap anak tetapi anak memutuskan apa-apa yang diinginkannya sendiri baik orang tua setuju ataupun tidak. Pola ini bersifat children centered maksudnya adalah bahwa segala aturan dan ketetapan keluarga berada di tangan anak.

\section{Pola Asuh Demokratis}

Pola asuh demokratis menggunakan komunikasi dua arah. Kedudukan antara orang tua dan anak dalam berkomunikasi sejajar. Suatu keputusan diambil bersama dengan mempertimbangkan (keuntungan) kedua belah pihak (win-win solution). Anak diberi kebebasan yang bertanggung jawab. Artinya, apa yang dilakukan anak tetap harus ada di bawah pengawasan orang tua dan dapat dipertanggung jawabkan secara normal. Menurut Hurlock, pola asuh demokratis memperlihatkan ciri-ciri adanya kesempatan anak untuk berpendapat mengapa ia melanggar peraturan sebelum hukuman dijatuhkan, hukuman diberikan kepada perilaku salah, dan memberi pujian ataupun hadiah kepada perilaku yang benar.

Menurut Sofia (Madyawati, 2016) ada beberapa faktor yang mempengaruhi pola asuh orang tua, yaitu:

\section{A. Faktor Sosial Ekonomi}

Lingkungan sosial berkaitan dengan pola hubungan atau pergaulan yang dibentuk oleh orang tua maupun anak dengan lingkungan sekitarnya. Anak dari orang tua yang sosial ekonominya rendah cenderung tidak melanjutkan pendidikan ke jenjang yang lebih tinggi atau bahkan tidak pernah mengenal bangku pendidikan sama sekali karena terkendala faktor status ekonomi.

\section{B. Pendidikan}

Pendidikan berarti pemberian bimbingan atau pertolongan yang diberikan dengan sengaja terhadap anak didik oleh orang dewasa agar ia menjadi dewasa. Latar belakang pendidikan orang tua dapat memperngaruhi pola pikir orang tua baik formal maupun non formal, lalu akan berpengaruh pada aspirasi atau harapan orang tua kepada anaknya.

C. Nilai Agama yang Dianut oleh Orang Tua

Nilai-nilai agama juga menjadi hal penting yang ditanamkan orang tua kepada anak dalam pengasuhan yang mereka lakukan sehingga Lembaga keagamaan turut berperan didalamnya. Orang tua yang kuat agamanya sudah terbiasa melaksanakan amalan-amalan agama, sehingga akan lebih mudah 
Jurnal PG-PAUD Trunojoyo : Jurnal Pendidikan dan Pembelajaran Anak Usia Dini, Volume 7, Nomor 2, Oktober 2020 hal 52-61, ISSN : 2528-3553 (online), ISSN: 2407-4454 (print)

mengajarkan agama kepada anaknya, jadi orang tua juga akan dapat lebih memperhatikan perkembangan anaknya dengan baik sehingga menghasilkan generasi unggul.

D. Kepribadian

Dalam mengasuh anak, orang tua tidak hanya mengomunikasikan fakta, gagasan, dan pengetahuan saja, melainkan membantu menumbuh kembangkan kepribadian anak. Penerapan kepribadian yang baik dapat memliki pola pengasuhan yang baik untuk anak.

E. Jumlah Pemilikan Anak

Jumlah anak yang dimiliki keluarga akan mempengaruhi pola asuh yang diterapkan para orang tua. Semakin banyak jumlah anak dalam keluarga, aka nada kecenderungan orang tua tidak begitu menerapkan pola pengasuhan secara maksimal pada anak karena perhatian dan waktunya terbagi antara anak satu dan lainnya.

Keterlambatan berbicara adalah hambatan yang di alami pada perkembangan berbicara yang mengakibatkan anak tidak dapat berkomunikasi secara lancar sehingga dapat berpengaruh pada penyesuaian diri pada lingkungan sosial anak tersebut.

Keterlambatan dalam berbicara memiliki jenis yang berbeda-beda satu dengan yang lainnya yang ditunjukkan dengan gangguan yang di alami oleh anak. Jenis keterlambatan dalam berbicara pada anak usia dini tersebut menurut Van Tiel (Tsuraya, 2013) antara lain : 1) Specific Language Impairment, 2) Speech and Language Expressive Disorder, 3) Centrum Auditory Processing Disorder, 4) Pure Dysphatic Development, 5) Gifted Visual Spatial Learner, 6) Disynchronous Developmental.

Banyak penyebab keterlambatan bicara, yang paling umum adalah rendahnya tingkat kecerdasan yang membuat anak tidak mungkin belajar berbicara sama baiknya seperti teman sebaya mereka yang kecerdasannya normal atau tinggi; kurang motivasi karena anak mengetahui bahwa mereka dapat berkomunikasi secara memadai dengan bentuk prabicara dorongan orang tua untuk terus menggunakan "bicara bayi" karena mereka mengira yang demikian "manis"; terbatasnya kesempatan praktek berbicara karena ketatnya batasan tentang seberapa banyak mereka diperkenankan bicara di rumah; terus menerus bergaul dengan saudara kembar yang dapat memahami ucapan khusus mereka dan penggunaan bahasa asing di rumah yang memperlambat memperlajari bahasa ibu.

\section{METODE PENELITIAN}

Penelitian ini menggunakan penelitian kualitatif, dengan pendekatan studi kasus. Menurut Moleong (2017), mendefinisikan bahwapenelitian kualitatif adalah tradisi tertentu dalam ilmu pengetahuan sosial yang secara fundamental bergantung dari pegamatan pada manusia baik dalam kawasannya maupun dalam peristiwanya. Pengumpulan data dalam penelitian ini menggunakan teknik triagulasi, mengumpulkan data dengan teknik, wawancara, observasi, dan dokumentasi (Barnawi \& Darajot, 2018).

\section{HASIL DAN PEMBAHASAN}

Berdasarkan hasil observasi dan wawancara mengenai dampak pola asuh orang tua terhadap anak yang mengalami gangguan berbicara yang telah dilakukan berkala pada tanggal 19 Maret 2020 sampai dengan 20 Juni 2020, telah didapatkan hasil sebagi berikut.

Pola asuh yang diterapkan terhadap anak yang mengalami gangguan berbicara yang bernama MM yaitu pola asuh permisif orang tua MM sebelumnya tidak memahami jika dalam mendidik dan merawat anak harus menggunakan pola asuh agar nantinya karakter dan kepribadian anak sesuai yang di harapkan oleh kedua orang tuanya. 
Jurnal PG-PAUD Trunojoyo : Jurnal Pendidikan dan Pembelajaran Anak Usia Dini, Volume 7, Nomor 2, Oktober 2020 hal 52-61, ISSN : 2528-3553 (online), ISSN: 2407-4454 (print)

Dalam penelitian ini MM memliki latar belakang keluarga yang lengkap, akan tetapi memiliki ekonomi yang kurang mampu dan orang tua MM memiliki latar belakang pendidikan yang kurang. Sehingga mendapat masalah karena orang tua MM kurang pengetahuan sehingga tidak tahu pola asuh apa yang baik untuk mendidik MM.

Akan tetapi karena kurangnya pengetahuan dan ekonomi yang kurang, orang tua MM tidak bisa melakukan apa-apa untuk memberikan fasilitas khusus seperti mendatangkan guru khusus, atau pun seorang terapis yang harus diberikan agar bisa mendidik seorang anak terlebih lagi anak yang harus diberikan perlakuan khusus seperti anak yang mengalami gangguan berbicara seperti MM.

Terdapat dampak yang ditimbulkan dari gangguan berbicara anak yang mengalami gangguan berbicara mempunyai masalah dalam berkomunikasi dengan orang lain sehingga pada saat anak berkomunikasi tidak bisa memahami apa yang ingin anak tersebut sampaikan oleh sebab itu sosialisasi anak akan kurang dan bisa menyebabkan anak jadi kelihatan murung, pendiam, dan tidak bersemangat oleh sebab itu orang tua juga harus tahu pola asuh yang baik yang bisa digunakan untuk anak yang mengalami gangguan berbicara.

Pada saat peneliti melakukan observasi dengan mendatangi rumah langsung ke rumah objek penelitian yaitu rumah MM. Dalam selain kesehariannya ibu PW sebagai ibu Rumah Tangga, ibu PW juga bekerja menjadi petani kebun karet sedangkan suaminya yang bernama SM bekerja sebagai buruh petani karet dan menjadi penggembala ternak sapi. Keluarga MM yang terdiri dari ayah, ibu, kakak perempuan, nenek dan kakek yang tinggal persis di sebelah rumah MM.

Peneliti datang dengan maksud meminta izin kepada ayah SM dan ibu PW untuk melakukan penelitian yang objek penelitiannya adalah MM. Sebelum melakukan penelitian peneliti melakukan observasi terlebih dahulu, dari observasi yang peneliti lakukan dapat disimpulkan bahwa anak yang mengalami gangguan berbicara ini merupakan anak yang murung dan pendiam, jika di tempat yang cukup ramai orang. Tetapi orang tua MM cenderung lebih memanjakan MM dengan memberinya kebebasan. Pada saat MM ingin membeli petasan orang tua MM langsung membelikannya tanpa memikirkan dampak apa yang akan terjadi jika anak kecil sudah bermain petasan jika membawa korek api sendiri tetapi jika tidak perbolehkan bermain petasan maka MM akan menangis dan berteriak, sehingga membuat orang tua MM tidak tega.

Dari kejadian ini peneliti menyimpulkan orang tua yang terlalu memberi kebebasan dan memanjakan anak sehingga jika ada sesuatu hal yang dia inginkan tidak diberikan maka anak tersebut memberontak dan marah karena biasanya selalu diberikan dan diperbolehkan apa saja yang dia inginkan.

Kejadian yang terjadi di lapangan pada pukul 09.30 WIB, peneliti melihat tingkah laku MM yang sedang marah karena tidak boleh memainkan korek api, MM mengoceh kepada kakek laki-lakinya yaitu mbah $\mathrm{M}$ karena mbah $\mathrm{M}$ melarang $\mathrm{MM}$ menggunakan korek api karena itu sangat berbahaya jika sampai mengenai bagian tubuh MM. Tetapi MM malah balik mengoceh tidak jelas apa yang MM ucapkan, hanya saja MM mengoceh dan berteriak kepada mbah $\mathrm{M}$.

Dari kejadian ini peneliti menyimpulkan kejadian ini adalah karena MM sering di perlakukan manja oleh orang tuanya sehingga membuat MM menjadi anak yang tidak disipiln dan melakukan apa saja yang dianggapnya benar dan tidak mau mendengarkan nasehat dari orang lain (egois).

Kejadian yang berlangsung di pagi hari, karena ayah SM dan ibu PW pergi ke kebun, MM dirumah hanya dengan kakak perempuannya saja. Karena MM ingin 
Jurnal PG-PAUD Trunojoyo : Jurnal Pendidikan dan Pembelajaran Anak Usia Dini, Volume 7, Nomor 2, Oktober 2020 hal 52-61, ISSN : 2528-3553 (online), ISSN: 2407-4454 (print)

mengambil handphone kakak perempuannya. Tapi kakak perempuannya meminta mbah $\mathrm{M}$ untuk memberitahu kepada MM bahwa handphonenya tidak bisa hidup karena sudah habis baterai tetapi MM tetap tidak percaya dan marah kepada mbah $\mathrm{M}$ dengan mengoceh dan mengambil kayu untuk di pukulkannya kepada mbah $\mathrm{M}$.

Dari kejadian ini peneliti dapat menyimpulkan bahwa MM tidak bisa lagi di beritahu ataupun di tegur sehingga jika dia ditegur ataupun beritahu tidak akan pernah mendengarkan dan siapapun bisa jadi target kemarahannya jika dia marah.

Kejadian ini terjadi pada sore hari, MM sering memegang korek api sendiri dan jika MM memegang korek api maka biasanya MM mencari kertas ataupun plastik, yang dibakar di atas genting untuk atap rumah. Terkadang jika MM ingin meminta korek tetapi tidak diberikan maka MM langsung menangis dan berteriak karena orang tua MM tidak bisa menahan karena kasihan melihat MM menangis akhirnyapun diberikan korek api tersebut.

Dari kejadian ini peneliti menyimpulkan bahwa orang tua $\mathrm{MM}$ membiasakan dengan memberikan apa saja yang di inginkan oleh MM, sehingga membuat anak tersebut terbiasa dengan apapun yang diberikan oleh orang tua sehingga membuat anak tidak kreatif.

Pola asuh orang tua menjadi sangat penting karena menjadi patokan berhasil tidaknya orang tua dalam mendidik dan merawat anak untuk masa depan yang akan datang. Oleh karenanya keluarga adalah pendidikan yang utama dalam pembelajaran seorang anak karena anak dapat meniru apa saja dari tingkah laku orang tuanya.

Oleh sebab itu orang tua juga harus lebih memperhatikan dan memahami cara mendidik dan merawat anak karena pembelajaran anak bukan hanya dengan guru di sekolah saja tetapi dirumah juga karena waktu yang di habiskan dengan orang tua lebih banyak dan panjang dari pada dengan guru di sekolah. Dengan demikian orang tua dan guru harus sejalan dan sesuai dalam mendidik dan merawat anak.

Orang tua juga harus lebih memahami karakter anak dan masalah apa yang telah di hadapi anak, sebelum menjadi orang tua harus menyiapkan secara matang mental maupun fisik untuk merawat dan mendidik buah hati sepenuh hati. Dalam mendidik anak tidak boleh sembarangan karena harus butuh pertimbangan yang matang untuk mendidik anak menggunakan pola asuh apa.

Ayah dan ibu juga dalam mendidik anak harus sejalan dan tidak boleh adanya bentrokan atau pertengakaran nantinya dalam mendidik anak, karena jika keduanya memiliki perbedaan pendapat harus di bicarakan dulu dan ambil jalan tengahnya yang baik seperti apa jangan sampai nantinya ada kata-kata saling menyalahkan karena mendidik anak dengan salah dengan menyalahkan saling menyalahkan salah satunya. Oleh sebab itu keuda orang tua harus lebih memahami bagaimana pola pengasuhan yang baik di gunakan dengan banyak-banyak mencari informasi, membaca buku dan bisa juga dengan bertanya dengan dokter anak.

Menurut Widyorini \& Van Tie (2017) menyatakan bahwa masalah bicara dan bahasa anak-anak ini adalah masalah ketertinggalan perkembangan. Jika dilihat dalam sebuah spektrum perkembangan bahasa, perkembangan bahasa anak-anak ini berada dalam spektrum yang paling bawah. Anak yang menjadi objek penelitian ini bernama munaroh yang akrab biasanya di panggil mumun. Ibu mumun bernama purwati, bapak mumun bernama satiman, dan kakak perempuan mumun bernama desti. Karena mumun ini besar dikeluarga yang kurang mampu sehingga orang tua mumun juga tidak bisa berbuat apa-apa.

Kalau MM ternyata mengalami gangguan keterlambatan sepengetahuan orang tuanya mumun hanya belum saatnya saja bisa 
Jurnal PG-PAUD Trunojoyo : Jurnal Pendidikan dan Pembelajaran Anak Usia Dini, Volume 7, Nomor 2, Oktober 2020 hal 52-61, ISSN : 2528-3553 (online), ISSN: 2407-4454 (print)

berbicara tetapi ternyata sampai umur 5 tahun mumun belum sepenuhnya dapat berbicara dengan lancar dan jelas seperti temantemannya seusianya.

Seharusnya mumun disekolahkan di sekolah yang lebih mengerti kondisinya akan tetapi karena kurangnya biaya maka mumun di sekolahkan disekolah yang sama seperti anak normal lainnya. Oleh karena itulah mumun sering kali di jahili dan diejek temantemannya di sekolah. Di sekolahpun tidak ada yang bisa mengerti apa yang dikatakan oleh mumun selain ibunya oleh karena itu ibu mumun setiap pagi mengantar dan menunggu mumun sampai pulang.

Gangguan/terlambat berbicara yang di alami MM, meliputi beberapa faktor yaitu sebagai berikut:

a. Faktor genetik

Menurut orang tuanya karena faktor genetik, di keluarganya ada juga yang mengalami gangguan berbicara yaitu tantenya $\mathrm{MM}$ itu sendiri tetapi menurut keterangan orang tua MM bahwa tante itu sekarang sudah bisa bicara oleh karena itulah orang tua MM pun tidak terlalu khawatir karena mereka yakin bahwa nantinya MM pun bisa berbicara dengan lancar seperti tantenya

b. Minimnya di ajak berkomunikasi

Berdasarkan informasi yang di dapatkan bahwa faktor lain menyebabkan MM terlambat berbicara karena kurang/minimnya diajak komunikasi karena orang tua sering kali berangkat pagi-pagi sekali dari rumah untuk pergi ke kebun, jika siang pulang sering kali ibunya MM menfaatkan itu untuk istirahat sedangkan bapaknya MM seringkali jika sudah pulang dari kebun istirahat sebentar langsung pergi lagi mencari rumput untuk ternak makanan sapi.

c. Ekonomi rendah/kurang mampu

Faktor ekonomi juga menjadi faktor pentingnya terlambat berbicara karena orang tua sudah mengetahui jika anak mengalami hambatan/gangguan berbicara tetapi karena kurangnya ekonomi membuat orang tua tidak bisa banyak berbuat apaapa yang seharusnya di diberikan kepada anak yang mengalami gangguan berbicara seperti, terapis dan guru khusus.

d. Kurangnya Pengetahuan Orang Tua

Karena orang tua mengalami kekurangan pengetahuan sehingga menanggapi anak yang mengalami gangguan berbicara dengan biasa saja karena orang tua tidak tahu apa yang akan terjadi jika hambatan/gangguan berbicara itu tidak di perhatikan dengan serius akibatnya pasti akan menganggu pertumbuhan dan perkembangan anak itu sendiri yang akan menjadi hambatan untuk kehidupannya di masa depan.

Orang tua MM yaitu ibu PW dan bapak SM menggunakan pola asuh permisif yang lebih cenderung memanjakan anak sehingga membuat anak jadi lebih sedikit egois, tidak mandiri dan sulit menyesuaikan diri di lingkungan.

Terdapat dampak yang ditimbulkan dari gangguan berbicara anak yang mengalami gangguan berbicara mempunyai masalah dalam berkomunikasi dengan orang lain sehingga pada saat anak berkomunikasi tidak bisa memahami apa yang ingin anak tersebut sampaikan oleh sebab itu sosialisasi anak akan kurang dan bisa menyebabkan anak jadi kelihatan murung, pendiam, dan tidak bersemangat oleh sebab itu orang tua juga harus tahu pola asuh yang baik yang bisa digunakan untuk anak yang mengalami gangguan berbicara.

Sehingga dampak dari anak yang mengalami gangguan berbicara menyebabkan anak sering dikucilkan oleh teman-temannya sehingga MM sulit dalam berinteraksi di sekitarnya karena sama-sama sulit memahami karena terbatasnya komunikasi sehingga mengakibatkan perselisihan atau pertengkaran dengan teman sebayanya. Apalagi sampai membuat MM trauma karena sering 
Jurnal PG-PAUD Trunojoyo : Jurnal Pendidikan dan Pembelajaran Anak Usia Dini, Volume 7, Nomor 2, Oktober 2020 hal 52-61, ISSN : 2528-3553 (online), ISSN: 2407-4454 (print)

dikucilkan di sekolah sehingga tidak ada teman yang mau bermain dengannya. Menurut cerita orang tuanya mumun pernah tidak mau sekolah karena takut temantemannya akan mengganggunya lagi. Karena itu mumun di sekolah menjadi murid yang pendiam dan pemurung.

Pada tanggal 19 Februari 2020 peneliti mulai melakukan pendekatan kepada MM dengan mengantarnya setiap pergi sekolah awalnya MM masih sedikit malu-malu sehingga ibunya pun masih ikut mengantar pada hari pertama. Setelah pulang sekolahpun peneliti datang ke rumah MM untuk lebih bisa mengenal karakter seorang MM karena. Setelah seminggu berlalu baru MM mulai tidak malu lagi dengan peneliti sehingga terkadang dia selalu menanyakan kepada ibu PW dimana peneliti kalo sehari saja tidak datang kerumahnya karena peneliti mengantar sekolah dan mengajari MM di sekolah.

Setelah beberapa lama penelitipun jadi semakin dekat dengan MM karena peneliti setiap pagi mengantar sekolah dan mengajari MM saat belajar dirumah maupun disekolah MM sekarang tidak malu-malu lagi dan tidak takut lagi pergi ke sekolah hanya saja MM hanya bisa memanggil peneliti saja jika ditanya MM tidak berbicara hanya mengganggukkan kepalanya saja atau menggelengkannya. Karena MM sudah sangat dekat dengan peneliti MM mengikuti apa saja yang di beritahukan oleh peneliti tetapi berbeda dengan orang tuanya MM selalu tidak mendengarkan apa yang dikatakan oleh orang tuanya. Karena orang tua MM dari kecil memakai pola asuh permisif kepada MM yang cenderung memanjakan MM sehingga sangat sulit sekali di atur jika diberitahu MM akan mengoceh seakan bahwa yang dilakukannya itu adalah benar dan tidak mau menurut.

Karena orang tua MM awalnya juga tidak terlalu mengerti pola asuh karena kurangnya pengetahuan dalam mendidik anak oleh sebab itu orang tua MM tidak tahu bahwa pola asuh itu juga penting untuk pertumbuhan anak. Sehingga orang tua MM baru tahu bahwa pola asuh yang di pakai mereka adalah pola asuh permisif yang cenderung memanjakan dan memberi kebebasan pada anak tanpa memberikan batasan-batasan tertentu yang harus dipatuhi oleh anak sehingga membentuk karakter yang kurang disiplin, egois, kurang kreatif dan mempunyai masalah dalam menyesuaikan diri dilingkungan sekitar.

Dari kesimpulan di atas bahwa pola asuh orang tua itu sangat mempengaruhi perkembangan dan pertumbuhan anak oleh karena itu orang tua harus tahu apa saja yang perlu di perhatikan dalam mindidik anak. Cara mendidik anak juga sangat penting dalam membentuk karakter dan kepribadian anak tersebut maka dari itulah orang tua harus mengerti dulu apa itu pola asuh.

Dengan begitu akan lebih mudah mendidik dan mengarahkan anak terssebut. Karena masa pandemi terpaksa sekolah dirumah jadi MM setiap hari ke rumah peneliti untuk mengerjakan tugas yang di beri dari sekolah. MM adalah anak yang rasa ingin tahunya tinggi sehingga jika kita ajari beberapa kali dan di ulang-ulang biasanya MM dalam menulis atau bernyanyi biasanya MM langsung bisa menirukan.

MM mempunyai salah seorang teman yang dekat dengannya, temannya tersebut berinisial NV, MM dan NV selalu bermain bersama hanya NV yang selalu menjadi temannya. Karena NV berbeda dengan teman yang lainnya karena biasanya teman-teman yang lain itu mengejek dan sering mengganggu MM, tetapi NV tidak seperti itu $\mathrm{NV}$ sering mengajak MM bermain sehingga mereka sangat dekat.

Peneliti malakukan wawancara dengan nenek kakek dan tetangga sekitar rumah mumun, menurut nenek dan kakek yang bernama mbah GY dan mbah $\mathrm{M}$, "neng keluorgoku dek biyen yo enek seng urong iso boco koyok MM, makane yo yakin wae nek engko MM yo iso boco koyok mbokde ne seng 
Jurnal PG-PAUD Trunojoyo : Jurnal Pendidikan dan Pembelajaran Anak Usia Dini, Volume 7, Nomor 2, Oktober 2020 hal 52-61, ISSN : 2528-3553 (online), ISSN: 2407-4454 (print)

penting yakin wae lah karo legowo wae kambek ujian seng dikei seko gusti alloh".

Sedangkan wawancara peneliti dengan ibu R, menurut ibu R "MM ki wong nge ki ceria karo semangat sakjane ki tapi kambek konco-konco seng liane $k i$ di enyek-enyek koyok ngono lo dadi ne dekne ki emoh dolanan nek di enyek ki, makane MM ki dadi wongnge menengan nek wong akeh saiki, gak gelem kambek wong seng nakal".

Dari wawancara peneliti dengan tetangga sekitar rumah mumun yang bernama ibu EW, kata ibu EW “ MM sebenarnyo budaknyo tu galak maen dewek kalo maen dewek singgonyo rebut nian dio sampe galak teriak-teriak oleh semangatnyo. Galak cak nomong dewek dio tu, nyanyi-nyanyi jugo tapi dak ngerti apo dio yang di omonginyo galak dak jelas dio ngomongnyo, MM jugo galak kumat budaknyo pernah waktu itu ado kawan ayuknyo datang nak maen tapi dak bolehnyo masuk rumah langsung di tutupnyo bae pintu rumah dak bolehnyo masuk, dang lagi kumatnyo mak itulah".

Kemudian wawancara peneliti dengan salah seorang teman MM, yang berinisial NV mengatakan "MM ki ngomongnge gak jelas lo kadanganne, tapi engko enek seng jelas saitik ngomongnge tapi rodok jarang. Nek neng omah MM dolanane kambek aku, nek kambek konco liane emoh olehhe MM di enyek-enyek terus lo kadangan dadi ne MM emoh biasane".

Kesimpulan diatas adalah orang tua yang menggunakan pola asuh permisif yang memberikan kebebasan, dan terlalu memanjakan anak akan menimbulkan masalah pada diri anak tersebut sehingga anak tidak bisa di atur, suka membantah, tidak perduli pada perkataan orang tua.

Berdasarkan penelitian yang saya lakukan cara mengatasi anak yang mengalami gangguan berbicara adalah orang tua harus mengerti permasalahan yang di hadapi oleh anak, jangan terlalu menganggap sepele persoalan perkembangan bahasa ini karena itu taruhannya adalah masa depan anak itu sendiri, orang tua juga harus perlu memahami pola karakteristik perkembangan dan kepribadian anak terlebih lagi anak yang mengalami keterlambatan bicara. Jadi orang tua juga harus ikut bertanggung jawab dalam memberikan mengarahkan dan membantu menstimulus bicara dan bahasa anak hingga bisa mencapai tahap atau tingkatan perkembangan bahasa yang lebih maksimal. Orang tua sangatlah dibutuhkan dalam pendampingan terus menerus sepanjang hari dan setiap hari, selain itu orang tua juga dapat meminta bantuan dari yang lebih ahli seperti ahli bahasa, para terapis atau sekolah.

\section{SIMPULAN DAN SARAN}

Berdasarkan hasil penelitian serta analisis penelitian yang peneliti lakukan, peneliti dapat menyimpulkan bahwa pola asuh orang tua yang digunakan pada anak yang mengalami gangguan berbicara dapat menggunakan pola asuh demokratis karena sebelumnya orang tua ibu dan bapak mumun menggunakan pola asuh permisif. Pola asuh yang sering digunakan ada tiga yaitu demokratis, permisif, dan otoriter. Maka dari itu pola asuh yang digunakan orang tua dalam mendidik anak sangat menentukan masa depan anak itu sendiri. Karena hubungan antara orang tua dan anak meliputi rasa cinta kasih, saling menyayangi, rasa tentram dan damai. Anak yang tumbuh di lingkungan keluarga akan meniru sikap dan tingkah laku orang tuanya terlebih dahulu oleh karena itu selain pola asuh sikap dan tingkah laku orang tua dapat mempengaruhi pertumbuhan dan perkembangan anak. Pendidikan pertama seorang anak adalah dari orang tuanya itu sendiri jika orang tua harus menanamkan nilai-nilai moral sedari dini, seperti sopan santun, tolong menolong, bersifat jujur, dan saling menyayangi.

\section{DAFTAR PUSTAKA}


Jurnal PG-PAUD Trunojoyo : Jurnal Pendidikan dan Pembelajaran Anak Usia Dini, Volume 7, Nomor 2, Oktober 2020 hal 52-61, ISSN : 2528-3553 (online), ISSN: 2407-4454 (print)

Aggraini, W. (2011). Keterlambatan Bicara (Speech Delay) pada Anak (Studi Kasus Anak Usia 5 Tahun). Jurusan Psikologi Fakultas Ilmu Pendidikan Universitas Negeri Semarang.

Barnawi \& Dajarot. (2018). Penelitian Fenomenologi Pendidikan (Teori dan Praktik).Yogyakarta: Ar-Ruzz Media.

Helmawati, P. K. (2014). Teoritis dan Praktis. Bandung: PT Remaja Rosdakarya, Cetakan Pertama.

Madyawati, L. (2016). Strategi pengembangan bahasa pada anak. Kencana.

Moleong, I. (2017). Metodologi Penelitian Kualitatif . Bandung: PT Remaja Rosdakarya Offset-Bandung.

Tsuraya, I. (2013). Kecemasan Pada Orang Tua Yang Memiliki Anak Terlambat Bicara (Speech Delay) Di RSUD Dr.M.Ashari Pemalang. Jurusan Psikologi Fakultas Ilmu Pendidikan Universitas Negeri Semarang.

Wibowo, Y. A., \& Daliman, S. U. (2018). Hubungan Antara Pola Asuh Otoriter dengan Keterampilan Sosial Anak (Doctoral dissertation, Universitas Muhammadiyah Surakarta).

Widyorini, E., \& Van Tiel, J. M. (2017). Disleksia: Deteksi, Diagnosis, Penanganan di Sekolah dan di Rumah. Kencana. 